9. Zubets, M. V., B. S. Prister, and G. A. Bogdanov. 2001. Problemy Chernobyl'skoy katastrofy $v$ deyatel'nosti UAAN - Problems of the Chornobyl catastrophe in activity of UAAN. Visnik agrarnoï nauki. Spetsial'niy vipusk, kviten' :5-10 (in Ukrainian).

10. Ovsyannikov, A. I. 1976. Osnovy opytnogo dela v zhivotnovodstve - Bases of an experience business in a stock-raising. Moskva. : Kolos, 302 (in Russian).

11. Prister, B. S., N. A. Loshchilov, O. F. Nemets, and V. A. Poyarkov. 1991. Osnovy sel'skokhozyaystvennoy radiobiologii - Bases of agricultural radiobiology.; 2-e izd. pererab. i dop. Kyiv. Urozhay. 472 (in Russian).

12. Plokhinskiy, N. A. 1969. Rukovodstvo po biometrii dlya zootekhnikov-Biometry guidance for animal technicians. Moskva : Kolos, 256 (in Russian).

13. Chernobyl'skaya katastrofa - Chornobyl catastrophe. pod. red. V. G. Bar'yakhtara. 1995. Kyiv,. Nauk.dumka, 560 (in Ukrainian).

УДК 636.39:591.465]:619

АНАТОМІЧНА БУДОВА ВНУТРІШНІХ СТАТЕВИХ ОРГАНІВ КІЗ ЗААНЕНСЬКОЇ ПОРОДИ

К. О. СКОРИК

Інститут розведення і генетики тварин імені М.В.Зубия НААН (Чубинське, Украӥна) gusi89@mail.ua

Козівництво - перспективна галузь тваринництва, яка стрімко розвивається. Наукова література має небагато інформації щодо суттєвих особливостей та відмінностей в будові статевого апарату кіз. Із збільшенням поголів'я та проведенням селекиіийної роботи в козівництві, знання особливостей статевої системи мають вагоме значення. В результаті досліджень була проведена анатомічна та морфометрична характеристика внутрішніх статевих органів кіз зааненської породи. Отримані дані є актуальними при плануванні проведення штучного осіменіння в козівництві.

Ключові слова: кози, статеві органи, матка, яєчники, розміри, маса

\title{
ANATOMICAL STRUCTURE OF INTERNAL GENITAL ORGANS ZAANEN BREE
}

K. O. Skorik

Institute of Animal Breeding and Genetics nd. a. M.V.Zubets of NAAS (Chubynske, Ukraine)

Goat breeding is a promising branch of animal husbandry, which is rapidly developing. The scientific literature has little information about the essential features and differences in the structure of the genital apparatus of goats. With the increase in the number of livestock and the selection in goat breeding, knowledge of the characteristics of the reproductive system is of great importance. As a result of the studies, anatomical and morphometric characteristics of the internal genital organs of goats of the Zaanen breed were carried out. The data obtained are relevant for planning artificial insemination in goat breeding.

Keywords: goats, genitals, uterus, ovaries, size, mass

\footnotetext{
с Науковий керівник - канд. с-г. наук С. Ю. Демчук

Розведення і генетика тварин. 2017. Вип. 53
}

() К. О. СКОРИК, 2017 


\section{АНАТОМИЧЕСКОЕ СТРОЕНИЕ ВНУТРЕННИХ ПОЛОВЫХ ОРГАНОВ КОЗ ЗААНЕНСКОЙ ПОРОДЫ}

\section{К. А.Скорик}

Институт разведения и генетики животных имени М.В.Зубиа НААН (Чубинское, Украина)

Козоводство - перспективная отрасль животноводства, которая стремительно развивается. Научная литература имеет немного информаџии о существенных особенностей и различий в строении полового аппарата коз. С увеличением поголовья и проведением селекционной роботы в козоводстве, знание особенностей половой системы имеют большое значение. В результате исследований была проведена анатомическая и морфометрическая характеристика внутренних половых органов коз зааненской породи. Полученные данные актуальны при планировании проведения искусственного осеменения в козоводстве.

Ключевые слова: козы, половые органы, матка, яичники, размеры, масса

Вступ. Основним методом досягнення тільності корів і телиць дотепер є штучне осіменіння. У перспективі воно повинно стати переважним і у вівчарстві та козівництві. Але внаслідок незнання особливостей будови статевих органів дрібної рогатої худоби знижується ефективність штучного осіменіння та неефективно використовується сперма плідників, оскільки складна будова шийки матки кіз і овець є перешкодою при штучному введенні сперми $[1,2,3$, $4,5]$.

У літературі є дані про особливості будови статевих органів, прояв їх функції в різних видів жуйних тварин. На знанні анатомо-фізіологічних особливостей самок базується багато біотехнологій відтворення сільськогосподарських тварин. Якщо ці питання стосовно корів і телиць висвітлено достатньо [1, 2, 3, 4, 5, 8, 11], у овець дещо менше [12, 13, 14, 15, 17], то про кіз зустрічаються лише окремі публікації $[7,10,17]$. Це сталося тому, що до останнього часу особливості розмноження кіз не цікавили спеціалістів 3 відтворення, вони були мало вивченими і переважала думка, що процеси розмноження у овець і в кіз відбуваються однаково. Прикладом цього слугує інструкція зі штучного осіменіння овець і кіз [9]. Однак спостереження працівників козівництва показали, що кози значно відрізняються за деякими ознаками прояву охоти [16], оригінальних досліджень дуже мало. Тому зважаючи на необхідність в подальшому впровадження в практику козівництва методу штучного осіменіння, дослідження особливостей будови внутрішніх статевих органів кіз $є$ своєчасними і необхідними.

Матеріали та методи досліджень. Дослідження анатомічних особливостей будови внутрішніх статевих органів кіз проводили на тваринах зааненської породи, завезених в с. Галайки Таращанського р-ну Київської області з Латвії. Матеріалом для вивчення були статеві органи, отримані від кіз у віці 6-7 років. Після забою та знекровлювання у кіз відділяли статеві органи. Потім їх розміщували у емальованій кюветі і вимірювали за допомогою мірної стрічки, лінійки та штангенциркуля. Досліджували лінійні розміри яєчників, діаметр і довжину рогів матки по великій кривизні, довжину тіла матки, довжину і діаметр шийки матки, кількість і особливості будови складок її слизової оболонки, кількість карункулів, їх висоту і діаметр. Площу карункулів розраховували за формулою $\mathrm{S}=\pi \mathrm{r}^{2}$, де $\pi$ - це математична константа, яка дорівнює 3,14 , a r - радіус круга. Внутрішні статеві органи зважували на лабораторних вагах.

Як уже вказувалося раніше, розробки анатомо-фізіологічних основ штучного осіменіння дрібних жуйних тварин проведені в основному на вівцях. Тому нами було співставлено розміри яєчників, яйцепроводів та матки у кіз зааненської породи латвійської селекції і за даними літератури проаналізовано результати досліджень аналогічних органів овець. Вказано [15], що в каналі шийки матки міститься до 8-ми поперечних складок, перші три - великі. У деяких овець шийки матки містять рідкі і товсті поперекові складки, які розміщені через 1-1,5 см одна від одної, а також з бородавчастими виступами. Розміри статевих органів овець породи прекос залежать від віку та живої маси маток. У ярок довжина шийки матки становить 4-6 см, є 4-6 поперечних складок висотою 0,1-0,8 см. У овець старше 2-х років шийка матки має довжину від 5 до 9 см, а в її каналі нараховується 5-8 поперекових складок. Перші від піхви 2-3 складки 
мають висоту від 1 до 1,7 см і нерідко заходять одна за одну. У більшості овець 80 \% складки суцільні або дещо розділені. Найбільш характерною є суцільно складчаста шийка на кожному сантиметрі якої розміщена одна складка.

1. Довжина статевих органів у овець породи прекос, см (М士m), Г.С. Шарапа, 1971

\begin{tabular}{|c|c|c|}
\hline Частини статевих органів & У віці до 2 років & У віці 3-9 років \\
\hline Піхва & $11,37 \pm 0,361$ & $12,62 \pm 0,150$ \\
\hline Шийка матки & $4,90 \pm 0,147$ & $6,57 \pm 0,108$ \\
\hline Тіло матки & $1,50 \pm 0,055$ & $2,05 \pm 0,057$ \\
\hline Правий ріг & $11,34 \pm 0,512$ & $15,29 \pm 0,318$ \\
\hline Лівий ріг & $11,20 \pm 0,522$ & $15,00 \pm 0,314$ \\
\hline Правий яйцепровід & $12,67 \pm 0,649$ & $14,16 \pm 0,221$ \\
\hline Лівий яйцепровід & $12,39 \pm 0,691$ & $1,59 \pm 0,036$ \\
\hline Правий яєчник: довжина & $1,11 \pm 0,081$ & $1,22 \pm 0,030$ \\
ширина & $0,85 \pm 0,060$ & $1,51 \pm 0,036$ \\
\hline Лівий яєчник: довжина & $1,12 \pm 0,062$ & $1,15 \pm 0,028$ \\
\hline ширина & $0,85 \pm 0,046$ & \\
\hline
\end{tabular}

У овець породи прекос розміри і вага статевих органів і окремих частин в онтогенезі зазнають змін. За ваги туш 20-23 кг їхні статеві органи мали параметри, вказані в таблиці 1.

Результати досліджень. Для успішного вирішення проблеми збільшення поголів'я худоби необхідні знання біології розмноження тварин, у тому числі знання будови і функції статевих органів. В літературі $є$ багато джерел щодо морфології статевих органів тварин. Однак публікацій, де висвітлюється будова статевих органів кіз, вкрай мало. В основному вони знаходяться в літературі давніх років. Це можна пояснити тим, що дослідження кіз, як промислових тварин, тривалий час не проводилися, і розпочалися, в основному, недавно.

Отримані дані щодо анатомічної будови внутрішніх статевих органів кіз заненської породи наведено у таблицях 2 і 3.

2. Розміри і маса парних статевих органів кіз $(n=4)$

\begin{tabular}{|c|c|c|c|c|c|c|}
\hline \multirow{3}{*}{$\begin{array}{l}\text { Сторони } \\
\text { розмі- } \\
\text { щення ор- } \\
\text { ганів }\end{array}$} & \multirow{3}{*}{$\begin{array}{c}\text { Статис- } \\
\text { тичні по- } \\
\text { казники }\end{array}$} & \multicolumn{5}{|c|}{ Органи } \\
\hline & & \multicolumn{2}{|c|}{ яєчники } & \multirow{2}{*}{$\begin{array}{l}\text { яйцепровід } \\
\text { довжина, см }\end{array}$} & \multicolumn{2}{|c|}{ ріг матки } \\
\hline & & $\begin{array}{c}\text { довжина, } \\
\text { см }\end{array}$ & мaca, $\Gamma$ & & довжина, см & діаметр,см \\
\hline \multirow{2}{*}{ Ліва } & $\mathrm{M} \pm \mathrm{m}$ & $2,0 \pm 0,06$ & $0,6 \pm 0,06$ & $14,2 \pm 0,16$ & $13,7 \pm 0,63$ & $2,3 \pm 0,07$ \\
\hline & $\mathrm{Cv}, \%$ & 6,6 & 12,3 & 2,3 & 9,1 & 6,4 \\
\hline \multirow{2}{*}{ Права } & $\mathrm{M} \pm \mathrm{m}$ & $2,4 \pm 0,04$ & $1,1 \pm 0,04$ & $14,4 \pm 0,15$ & $12,2 \pm 0,75$ & $2,8 \pm 0,08$ \\
\hline & $\mathrm{Cv}, \%$ & 5,4 & 9 & 2,1 & 12,2 & 6,1 \\
\hline
\end{tabular}

В результаті проведених досліджень морфологічних показників парних статевих органів кіз були отримані такі дані: маса лівого яєчника $-0,6 \pm 0,06$ г, правого $-1,1 \pm 0,04$ г: довжина

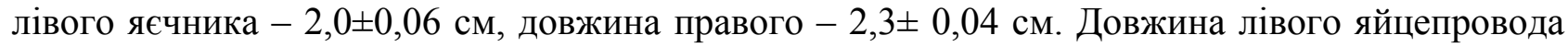

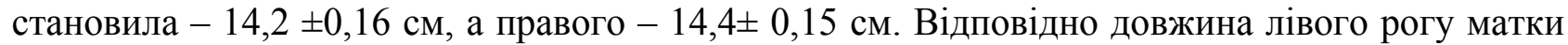
була $13,7 \pm 0,63 \mathrm{~cm}$, правого - 12,2 $\pm 0,75$ см. Діаметр лівого рогу $-2,3 \pm 0,07$ см, правого рогу матки $-2,8 \pm 0,08$ см.

Морфологічні показники непарних статевих органів наведено в таблиці 3. 
3. Розміри непарних статевих органів кіз

\begin{tabular}{|c|c|c|c|c|c|c|c|c|}
\hline & \multicolumn{9}{|c|}{ Органи } \\
\cline { 2 - 10 } & $\begin{array}{c}\text { тіло ма- } \\
\text { Скатис- } \\
\text { тичні по- } \\
\text { казники }\end{array}$ & \multicolumn{3}{|c|}{ шийка матки } \\
\cline { 2 - 10 } & $\begin{array}{c}\text { довжина, } \\
\text { см }\end{array}$ & $\begin{array}{c}\text { довжина, } \\
\text { см }\end{array}$ & $\begin{array}{c}\text { діаметр, } \\
\text { см }\end{array}$ & $\begin{array}{c}\text { число } \\
\text { складок }\end{array}$ & висота & $\begin{array}{c}\text { діаметр, } \\
\text { см }\end{array}$ & кількість & $\begin{array}{c}\text { площа } \\
\text { одного } \\
\text { карун- } \\
\text { кула, см }\end{array}$ \\
\hline $\mathrm{M} \pm \mathrm{m}$ & $1,8 \pm 0,15$ & $5,9 \pm 0,29$ & $1,8 \pm 0,08$ & $4,7 \pm 0,50$ & $0,5 \pm 0,06$ & $0,7 \pm 0,10$ & $96,5 \pm 1,70$ & $0,4 \pm 0,10$ \\
\hline $\mathrm{Cv}, \%$ & 8,1 & 9,8 & 9,3 & 20,1 & 26,5 & 23,1 & 3,5 & 41,1 \\
\hline
\end{tabular}

Довжина тіла матки становила $-1,8 \pm 0,15$ см, шийки матки - 5,9 90,29 см, діаметр шийки $-1,8 \pm 0,08$ см; число складок в шийці матки $-4,7 \pm 0,50$. Висота карункулів $-0,5 \pm 0,06$ см, їх

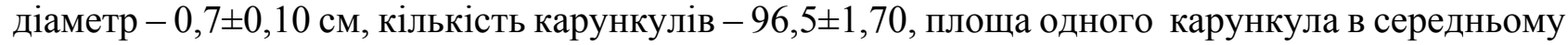
становила $-0,4 \pm 0,10 \mathrm{~cm}^{2}$. На рис. 1 та 2 показана будова матки та її шийки.

В літературі [17] описано розміри матки домашніх кіз. Роги матки мали довжину $8,5 \mathrm{~cm}$ лівий, та 8,6 см правий. Тіло матки було коротшим, ніж за отриманими нами даними - 0,77 см, а шийка матки мала довжину 2,4 см. Отже наші дані незначно, але трохи відрізняються від результатів, отриманих іншими авторами. Це, можливо, пояснюється породними особливостями розмірів внутрішніх статевих органів зааненських кіз.

Висновки. В результаті проведених досліджень дана анатомічна і морфометрична характеристики внутрішніх статевих органів кіз. Ці дані дають змогу розширити і доповнити знання з морфології статевої системи сільськогосподарських тварин, що потрібно враховувати при штучному осіменінні кіз. Отримані нами дані дещо відрізняються від результатів досліджень інших авторів, але не суперечать їм.

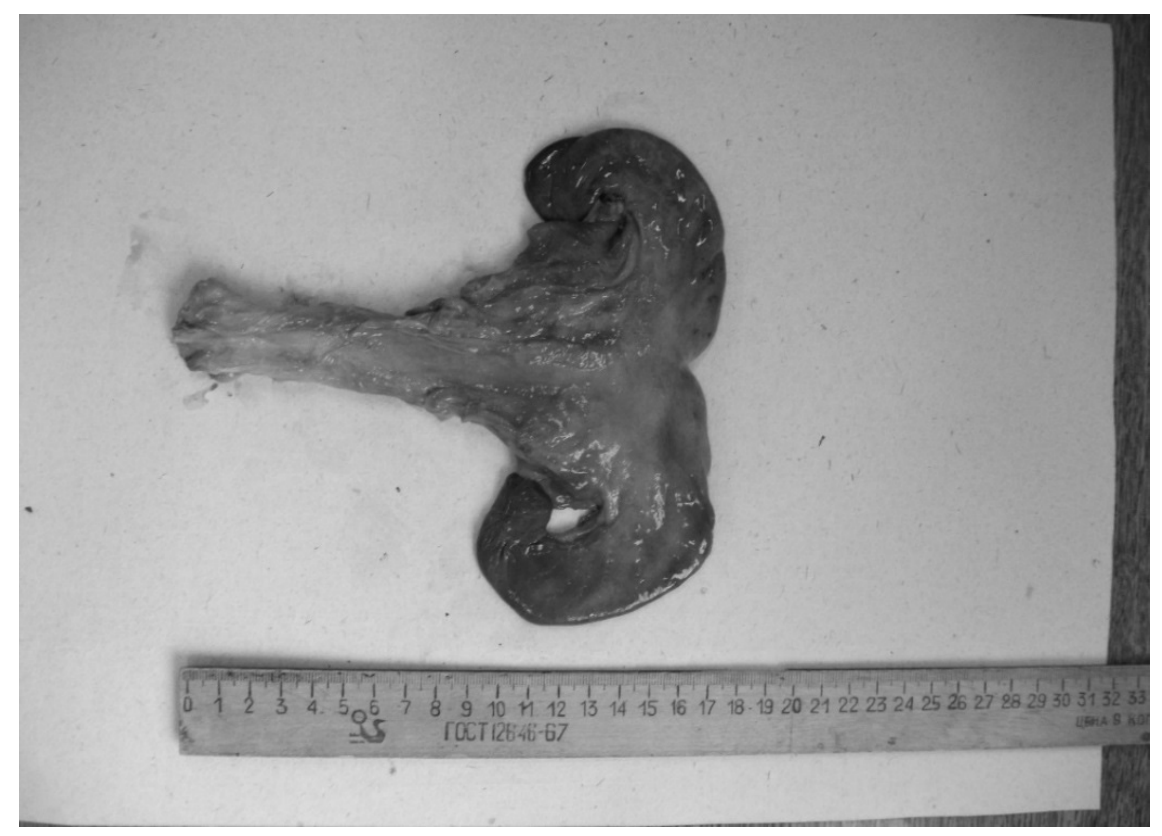

Рис. 1. Матка кіз зааненської породи 




Рис.2. Шийка матки кіз зааненської породи

\section{БІБЛІОГРАФІЯ}

1. Автократов, Д. М. Анатомия домашних животных / Д. М. Автократов. - М.: Сельхозгиз, 1949. -158 с.

2. Акаевский, А. А. Анатомия домашних животных / А. А. Акаевский, С. Н. Боголюбский, М. И. Лебедев - М.: Высш. шк., 1971. - Ч. 3. - 186 с.

3. Бочаров, И. А. Акушерство, гинекология и искусственное осеменение с.-х. животных / И. А. Бочаров, А. В. Бесхлебнов, Я. Г. Губаревич. - М: Колос, 1967. - 62-67 с.

4. Валюшкин, К. Д. Акушерство, гинекология и биотехнология размножения животных / К. Д. Валюшкин, Г. Ф. Медведев // М.: Урожай, 1997. - 718 с.

5. Глаголев, П. А. Анатомия сельскохозяйственных животных / П. А. Глаголев. - М.: Колос, 1977. - 322-344 с.

6. Демченко, А. Я. К сравнительной морфологии яичников домашних млекопитающих / А.Я. Демченко // Автореф. дисс. к.б.н. - Алма-Ата, 1954. - 25 с.

7. Джадранов, Е.С. Возрастные и морфологические изменения яичников коз / Е.С. Джадранов, К. Бердонгаров, И.И. Безруков // Вестник с.-х. Казахстана - Алма-Ата, 1985. - $42-43$ с.

8. Ермаченков, А.Н. Акушерство и гинекология с.-х. животных / А.Н. Ермаченков. - М.: Колос - $1983-146 \mathrm{c}$.

9. Інструкція із штучного осіменіння овець і кіз / [Ю.Ф. Мельник, Д.М. Микитюк, М.В. Зубець та ін.] під ред. О.М. Шевчук. - К., Аграрна наука - 2003 - 40с.

10. Карпов, В.А. Акушерство и гинекология мелких домашних животных / В.А. Карпов. - М.: Росагропромиздат, 1990. - 288 с.

11. Климов, А.Ф. Анатомия домашних животных / А.Ф. Климов. - М.: 1955. - 265-287 с.

12. Лобачова, І.В. Морфологія яєчників овець у різні місяці року / І. В. Лобачова // Біологія тварин. - 2016. - Т. 18, № 1. - С. 77-86.

13. Лопырин, А.И. Биология размножения овец / А.И. Лопырин. - М.: Колос, 1971 - 565 с.

14. Поликарпова, Е.Ф. Морфогенез яичников овец / Е.Ф. Поликарпова, М.В. Невзгодина. - М.: Наука, 1974. - 35 с.

15. Шарапа, Г.С. Штучне осіменіння овець 3 урахуванням будови їх статевих органів / Г.С. Шарапа. Племінна справа і біологія розмноження сільськогосподарських тварин. Республіканський міжвідомчий тематичний науковий збірник. - К.: Урожай, 1972. - Вип. 2. - С. 107110. 
16. DisserCat - электронная библиотека диссертаций. Научные основы интенсификации воспроизводства молочных коз: [Електронний ресурс]./ - Режим доступу:http://www.dissercat.com/content/nauchnye-osnovy-intensifikatsii-vosproizvodstvamolochnykh-koz.

17. Хибхенов, Л. В. Сравнительно-анатомические и морфометрические показатели половых органов самок домашних яков, коз и овец породы бубэй / Л. В. Хибхенов, Е. Ю. Алдарова // Науковий вісник Національного університету біоресурсів і природокористування України. Сер.: Ветеринарна медицина, якість і безпека продукції тваринництва. - 2013. - Вип. 188(2). - С. 187-193.

\section{REFERENCES}

1. Avtokratov, D.M. 1949. Anatomiya domashnikh zhivotnykh-Anatomy of domestic animals. Moscow, Sel'khozgiz, 158 (in Russian).

2. Akaevskiy, A.A., S.N. Bogolyubskiy and M.I. Lebedev. 1971. Anatomiya domashnikh zhivotnykh - Anatomy of domestic animals. Moscow, Ch.Z., 186 (in Russian).

3. Bocharov, I.A., A.V. Beskhlebnov and Ya.G. Gubarevich. 1967. Akusherstvo, ginekologiya $i$ iskusstvennoe osemenenie s.-kh. zhivotnykh - Obstetrics, gynecology and artificial insemination of agricultural animals. Moscow, Kolos, 62-67 (in Russian).

4. Valyushkin, K.D. and G.F. Medvedev. 1997. Akusherstvo, ginekologiya i biotekhnologiya razmnozheniya zhivotnykh - Obstetrics, gynecology and biotechnology of animal reproduction. Moscow, Urozhay, 718 (in Russian).

5. Glagolev, P.A. 1977. Anatomiya sel'skokhozyaystvennykh zhivotnykh-Anatomy of farm animals. Moscow, Kolos, 322-344 (in Russian).

6. Demchenko, A.Ya. 1954. K sravnitel'noy morfologii yaichnikov domashnikh mlekopitayushchikh - To the comparative morphology of ovaries in domestic mammals. Avtoref. diss. k.b.n. AlmaAta, 25 (in Russian).

7. Dzhadranov, E.S., K. Berdongarov and I.I. Bezrukov. 1985. Vozrastnye i morfologicheskie izmeneniya yaichnikov koz - Age and morphological changes in the ovaries of goats. Vestnik s.-kh. Kazakhstana. Alma-Ata, 42-43 (in Russian).

8. Ermachenkov, A.N. 1983. Akusherstvo i ginekologiya s.-kh. zhivotnykh-Obstetrics and gynecology of agriculture animals. Moscow, Kolos, 146 (in Russian).

9. Mel'nyk, Yu.F., D.M. Myky- tyuk and M.V. Zubets'. 2003. Instruktsiya iz shtuchnoho osimeninnya ovets' $i$ kiz - Instructions for artificial insemination of sheep and goats. Kyiv, Ahrarna nauka, 40 (in Ukrainian).

10. Karpov, V.A. 1990. Akusherstvo i ginekologija melkih domashnih zhivotnyh-Obstetrics and gynecology of small pets. Moscow, Rosagropromizdat, 288 (in Russian).

11. Klimov, A.F. 1955. Anatomija domashnih zhivotnyh-Anatomy of domestic animals. Moscow, 265-287 (in Russian).

12. Lobachova, I.V. 2016. Morfolohiya yayechnykiv ovec" u rizni misyaci roku - Ovarian Morphology sheep in different months of the year. Biolohiya tvaryn. - Animal Biology.1 (18): 77-86 (in Ukrainian).

13. Lopyrin, A.I. 1971. Biologija razmnozhenija ovec - Biology of reproduction of sheep. Moscow, Kolos, 565 (in Russian).

14. Polikarpova, E.F. and M.V. Nevzgodina. 1974. Morfogenez jaichnikov ovec-Morphogenesis of ovaries of sheep. Moscow, Nauka, 35 (in Russian).

15. Sharapa, H.S. 1972. Shtuchne osimeninnya ovets' z urakhuvannyam budovy yikh statevykh orhaniv - Artificial insemination of sheep taking into account the structure of their genitals. Respublikans'kyy mizhvidomchyy tematychnyy naukovyy zbirnyk. Kyiv, Urozhay. 2: 107-110 (in Ukrainian). 
16. DisserCat - jelektronnaja biblioteka dissertacij. Nauchnye osnovy intensifikacii vosproizvodstva molochnyh koz From http://www.dissercat.com/content/nauchnye-osnovy-intensifikatsiivosproizvodstva-molochnykh-koz (in Russian).

17. Hibhenov, L. V. 2013. Sravnitel'no-anatomicheskie i morfometricheskie pokazateli polovyh organov samok domashnih jakov, koz i ovec porody bubjej - Comparative-anatomical and morphometric parameters of the reproductive organs of female yaks, goats and sheep of the Bubei breed. Naukovij visnik Nacional'nogo universitetu bioresursiv i prirodokoristuvannja Ukraïni. Ser.: Veterinarna medicina, jakist' i bezpeka produkciï tvarinnictva - Scientific Bulletin of National University of Life and Environmental Sciences of Ukraine. Aug.: veterinary medicine quality and safety of animal products. 188(2): 187-193 (in Ukrainian).

УДК 636.2.064.082.454:636.2.084.1

\section{РОЗВИТОК І ЗАПЛІДНЕНІСТЬ ТЕЛИЦЬ ЗА РІЗНИХ СХЕМ ВИПОЮВАННЯ НЕЗБИРАНОГО МОЛОКА}

\section{Г. С. ШАРАПА, О. В. БОЙКО}

Інститут розведення і генетики тварин імені М.В.Зубия НААН (Чубинське, Україна)

boyko_lena@ua.fm

$\bar{B}$ ивчали розвиток 955 теличок при випоюванні 260, 310 і 360 кг незбираного молока $i$ згодовуванні передстартового комбікорму або повночінних гранул. Середня жива маса телички у 3 міс. становила 100,9 кг, у 6 міс. - 166, 2 кг, у 9 міс. - 239,2 кг, у 12 міс. - 308,6 кг, у 15 міс. - 371,5 кг. Відставали у рості 2,4-9,2\% теличок. Більше відставання (9,2\%) було у групі теличок, щзо випивали 260 кг молока (P>0,999). Особливої різниці в живій масі теличок, щзо випивали 310 і 360 кг молока, встановлено не було. Середньодобові прирости телиць становили 660-895 г. Статева зрілість у 24-30\% телиць наступала у віџі 9-10 міс. Виявлено 6,4\% 3 аномаліями статевих органів. Осіменіння телиць у віці 13-16 міс. при живій масі 365-380 кг забезпечує заплідненість від першого осіменіння на рівні 73,6\%. Середня продуктивність корів за дві лактації становила 7,5 тис. кг молока.

Ключові слова: телиці, розвиток, жива маса, незбиране молоко, заплідненість, продуктивність

\section{DEVELOPMENT AND FERTILITY OF HEIFERS UNDER DIFFERENT SCHEMES WATERING OF WHOLE MILK}

G. S. Sharapa, O. V. Boyko

Institute of Animal Breeding and Genetics nd. a. M.V.Zubets of NAAS (Chubynske, Ukraine)

We studied 955 heifers development during the watering of 260,310 and $360 \mathrm{~kg}$ of whole milk and feeding pre-feed full or granules. The average live weight of heifers in 3 months amounted to $100.9 \mathrm{~kg}$, in 6 months $-166.2 \mathrm{~kg}$, in 9 months - $239.2 \mathrm{~kg}$, in 12 months $-308.6 \mathrm{~kg}$, in 15 months $371.5 \mathrm{~kg}$. Behind in growth 2,4-9,2\% heifers. More backlog (9.2\%) were in the group of heifers that drinking $260 \mathrm{~kg}$ of milk $(P>0.999)$. The difference in live weight heifers that drank 310 and $360 \mathrm{~kg}$ of milk, has been established. Increase of live weight average of heifers 660-895 g. Sexual maturity at 24-30\% advancing heifers aged 9-10 months. Found 6.4\% of genital abnormalities. Insemination of heifers aged 13-16 months at 365-380 kg of live weight provides the first insemination fertility at $73.6 \%$. The average productivity of cows in two lactation was 7.5 thousand. $\mathrm{kg}$ of milk.

Keywords: heifers, development, live weight, whole milk, fertility, productivity 